\title{
PAJ BOOKS
}

BONNIE MARRANCA AND GAUTAM DASGUPTA, SERIES EDITORS

\section{Theatre of the Ridiculous}

revised and expanded edition

EDITED BY

BONNIE MARRANCA AND GAUTAM DASGUPTA

As a theatrical form, the "ridiculous" thrived in the 1960s and early 1970s, playfully subverting dramatic and social convention in its mix of camp, role-ploying, literary and filmic allusions-and anticipating by decades the current interest in gender, cross-dressing, and popular culture. Originally published in 1979.

Theatre of the Ridiculous was the first book to document this innovative and challenging work. This revised and expanded edition retains seminal works by Ronald Tavel, Charles Ludlam, and Kenneth Bernard and adds essays and interview material on each of these playwrights. Also new to the edition is Rehearsal for the Destruction of Atlantis by Jack Smith and an essay by J. Hoberman on Smith's work.

16 illustrations, E12.50 paperback

\section{ART+PERFORMANCE}

Art + Performance books provide critical introductions to artists who work at the junction of the visual arts and theater.

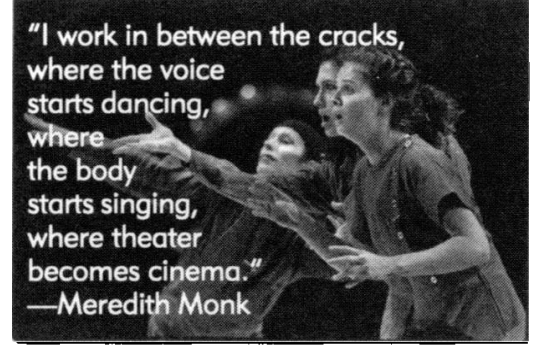

Meredith Monk EDITED BY
DEBORAH JOWITT

Meredith Monk's visionary work as performer, composer, choreogropher, filmmaker, singer, and dancer has helped to define the American avant garde and earned numerous honors and awards-including a MacArthur fellowship in 1995. Deborah Jowitt creates an absorbing portrait of an artist whose career spans three decades of American performance. Bringing together writings by Monk herself, along with reviews, essays, interviews, and photographs of Monk's unique performance events, the book establishes her as one of the great treasures of contemporary American culture.

24 illustrations, $£ 16.50$ poperback

\section{Rachel Rosenthal}

\section{EDITED BY MOIRA ROTH}

Moiro Roth brings together a powerful portrait of the woman the Village Voice calls "one of America's most intelligent, politically committed, and challenging performance artists." Featuring critical commentary, interviews, and photographs of Rosenthal's performances, and collecting for the first time a selection of her writings (including the script of Rachel's Brain) the book captures the voice of a unique American artist-one whose career reads like a history of performance art from the early 1950 s to the present.

21 illustrations, $£ 16.50$ paperback

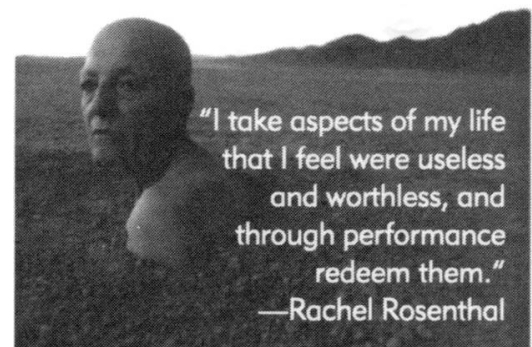




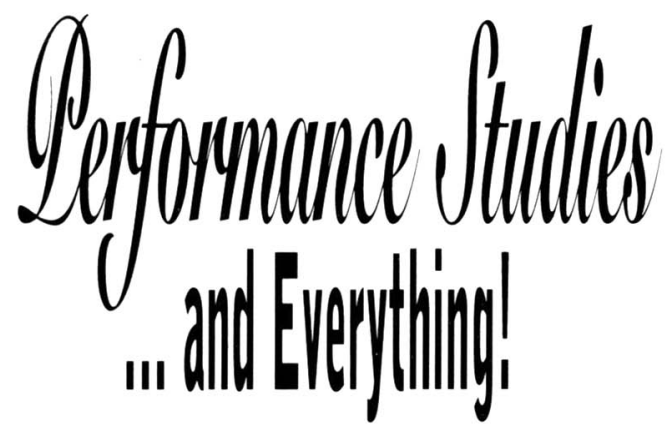

\section{PLAYING BIT PARTS IN SHAKESPEARE} M.M. Mahood

'A stunningly exhaustive family tree of

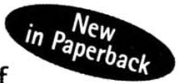

('bit parts'), Folio origins, and a comprehensive history to boot.' - SUNDAY TIMES

'A magisterial survey ... No director of Shakespeare can afford to be without Bit Parts. It is a fount of ideas.'

- RALPH BerRY

May 1998: 216x138: 304pp $\mathrm{Pb}: 0-415-18242-5:$ E13.99

\section{ACTORS ON GUARD}

A Practical Guide for the Use of the Rapier and Dagger for Stage and Screen

Dale Anthony Girard Actors on Guard provides the historical, theoretical and practical basis for understanding everything the actor needs to know in preparing for and presenting any stage fight.

January 1998: $7 \times 10$ : 450pp: illus. 271 b/w illus $\mathrm{Hb}: 0-87830-057-0$ : $€ 50.00 \quad \mathrm{~Pb}: 0-87830-058-9: \mathbf{E} 14.99$

\section{RENAISSANCE DRAMA IN ACTION}

Martin White, University of Bristol, UK

A fascinating exploration of Renaissance theatre practice and staging, which relates the characteristics of Renaissance theatre to the issues involved in staging the plays today. Plays discussed include 'The Duchess of Malfi:

May 1998: 234x156: 240pp: illus. $20 \mathrm{~b}+\mathrm{w}$ photos

Hb: 0-415-06738-3: $€ 45.00$ Pb: 0-415-06739-1: $€ 13.99$
ENGLISH STAGE COMEDY 1490-1900

The Persistence of a Genre

Alexander Leggatt

A unique and beautifully written study of the comedy of the English stage from the Tudor period to the late twentieth century. It shows how this remarkably enduring genre has dealt with the tensions of social life.

September 1998: 234x 156: 224pp

$H b: 0-415-18936-5$ : $€ 45.00$ Pb: 0-415-18937-3: £14.99

\section{READINGS IN RENAISSANCE WOMEN'S DRAMA}

Edited by S.P. Cerasano and Marion Wynne-Davies Brings together, for the first time, a significant collection of critical and historical essays. Authors include: Joanna Lumley, Elizabeth Cary, Mary Sidney, Mary Wroth and the Cavendish sisters.

September 1998: 216x138: 264pp

$\mathrm{Hb}: 0-415-16442-7: £ 45.00 \mathrm{~Pb}: 0-415-16443-5: £ 14.99$

\section{PERFORMANCE RESEARCH}

A Journal of Performing Arts Journal Edited by General Editor: Richard Gough, Centre for Performance Research and University of Wales, UK, Joint Editors: Claire MacDonald, De Montfort University, UK and Ric Allsopp, Dartington College of Arts, UK An innovative venture, Performance Research is the only journal of the performing arts to speak from Europe on European work, while relating it to the wider world in geographic, critical and historical terms. The themed issues are artfully produced and fully illustrated with photographs and drawings. Forthcoming issues include: On America, On Ploce and Praxis and On Ritual. PUBLICATION DETALLS:

Volume 3 is published in 1998: ISSN: 1352-8165: three issues per volume

\section{THE WORLD ENCYCLOPEDIA OF} CONTEMPORARY THEATRE

Volume 5: Asia and the Pacific

Edited by Ravi Chaturvedi, Ramendu Majumdar, Chua Soo Pong, Minoru Tanokura, and Katherine Brisbane

June 1998: 246x174: 488pp: illus. 135 photos $\mathrm{Hb}: 0-415-05933-\mathrm{X}: \mathbf{2 8 5 . 0 0}$

Routledge books are available from all good bookshops.

For more information or FREE Performance Studies catalogue, please contact: Cynthia Wainwright, Routledge, 11 New Fetter Lane, London EC4P 4EE. Tel: +44 (0) 1718422032 Fax: +44 fo:171 8422306 Email: info.performance@routledgecom Routledge On-Line: www.routledge.com

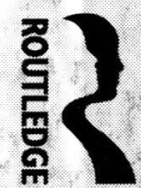

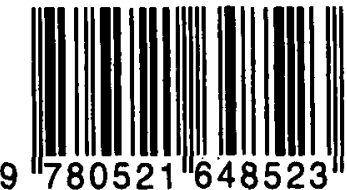

